\title{
A FETAL CASE OF PARTIAL TRISOMY 6q(q21-qter) WITH RENAL DYSPLASIA
}

\author{
Shinichi Miyabara, ${ }^{1}$ Hazime Toyoshima, ${ }^{1}$ and Kaoru Suzumori ${ }^{2}$ \\ ${ }^{1}$ Department of Pathology, Saga Medical School, \\ Nabeshima-machi, Saga 840-01, Japan \\ ${ }^{2}$ Department of Obstetrics and Gynecology, Nagoya City University \\ Medical School, Mizuho-ku, Nagoya 467, Japan
}

\begin{abstract}
Summary A fetal case of partial trisomy 6q(q21-qter) was reported. Renal dysplasia and coarctation of the aorta with persistent left superior vena cava were detected in the fetus in addition to the typical external phenotype, which has been described in children and adolescents with partial trisomy $6 \mathrm{q}$. The significance of associated abnormalities was briefly discussed.
\end{abstract}

\section{INTRODUCTION}

In a collaborative study of fetuses aborted after prenatal diagnosis (Miyabara et al., 1985), a case of partial trisomy $6 \mathrm{q}$ was encountered. This type of partial trisomy has not been fully documented. This report describes some morphological features of partial trisomy $6 \mathrm{q}$ in the fetal stage and discuss their developmental significance.

\section{CASE REPORT}

The fetus in question was the fifth product of a 33-year-old gravida 5 , ab 4 mother and a 33-year-old father, her second husband. This woman's first three pregnancies, all with her former husband, terminated in spontaneous abortions at about two or three months. Her fourth pregnancy, with her present husband, also terminated in a spontaneous abortion at four months. The cytogenetic examination of the fourth fetus revealed a karyotype $46, \mathrm{XY}, \operatorname{der}(7), \mathrm{t}(6 ; 7)(\mathrm{q} 21 ; \mathrm{p} 22)$. It was further observed that the mother was a balanced translocation carrier. She had a reciprocal translocation between the long arm of chromosome No. 6 and the short arm of chromosome No. 7. The break points occurred at bands $6 \mathrm{q} 21$ and $7 \mathrm{p} 22$, karyotype being $\mathrm{t}(6 ; 7)(\mathrm{q} 21 ; \mathrm{p} 22)$ (Figs. $1 \mathrm{~A}$ and $1 \mathrm{~B})$. 


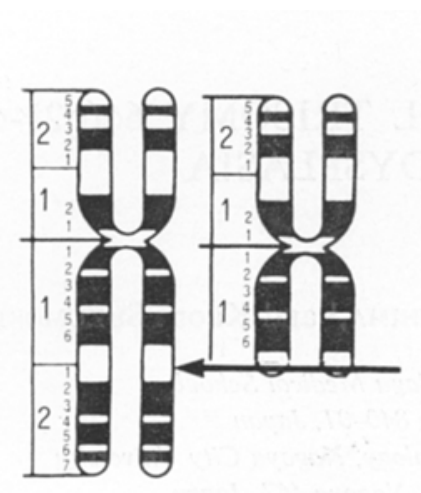

A

6

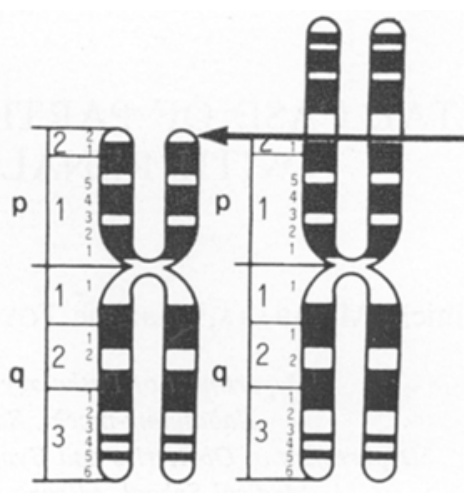

7

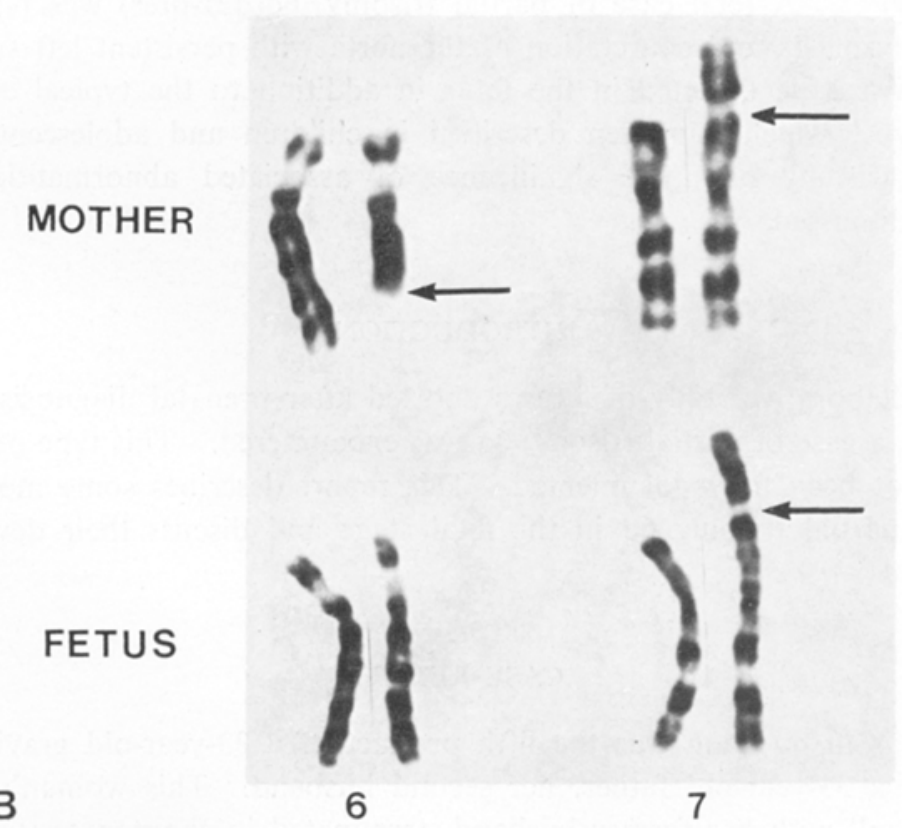

Fig. 1. A. Schematic illustrations of normal and derivative chromosomes 6 and 7 . Arrows indicate breakpoints. B. G-banded chromosomes 6 and 7 from the mother and the fetus: $t(6 ; 7)(\mathrm{q} 21 ; \mathrm{p} 22)$.

In the conception under discussion, the cytogenetic examination by amniocentesis at 17 weeks of pregnancy showed a partial trisomy 6q having an identical karyotype $46, \mathrm{XY}, \operatorname{der}(7), \mathrm{t}(6 ; 7)(\mathrm{q} 21 ; \mathrm{p} 22)$ mat (Figs. 1A and 1B) with that of the fourth fetus. The fetus was artificially aborted at 19 weeks. 


\section{AUTOPSY FINDINGS}

The fetus was autopsied after fixation in $10 \%$ formalin solution. The body weighed $385 \mathrm{~g}$. Crown-rump length, leg length and head circumference were 17.0 $\mathrm{cm}, 10.2 \mathrm{~cm}$ and $20.5 \mathrm{~cm}$, respectively. The forehead was wide and the eyes seemed to show hypertelorism. The nasal bridge was flat and broad, and the nasal ala was wide. The philtum was long and the mouth looked somewhat like a fish-mouth with thin lips (Fig. 2A). The chin was receding. The neck was short with moderate webbing (Fig. 2B). Both second fingers showed characteristic flection contracture. The penis seemed hypoplastic. Bilateral clubfeet were present (Fig. 2A).

The left superior vena cava persisted and coarctation of the aorta, preductal type, was recorded.

The kidneys exhibited a peculiar appearance. Macroscopically, the external surfaces of both kidneys had many small irregular-shaped nodules instead of the usual fetal lobation (Fig. 3A). The right ureter showed slight dilatation. Histologically, the nephrogenic tissues including nephroblastic cells, immature glomeruli and the tubules were only barely observable in the subcapsular counterpart area of the
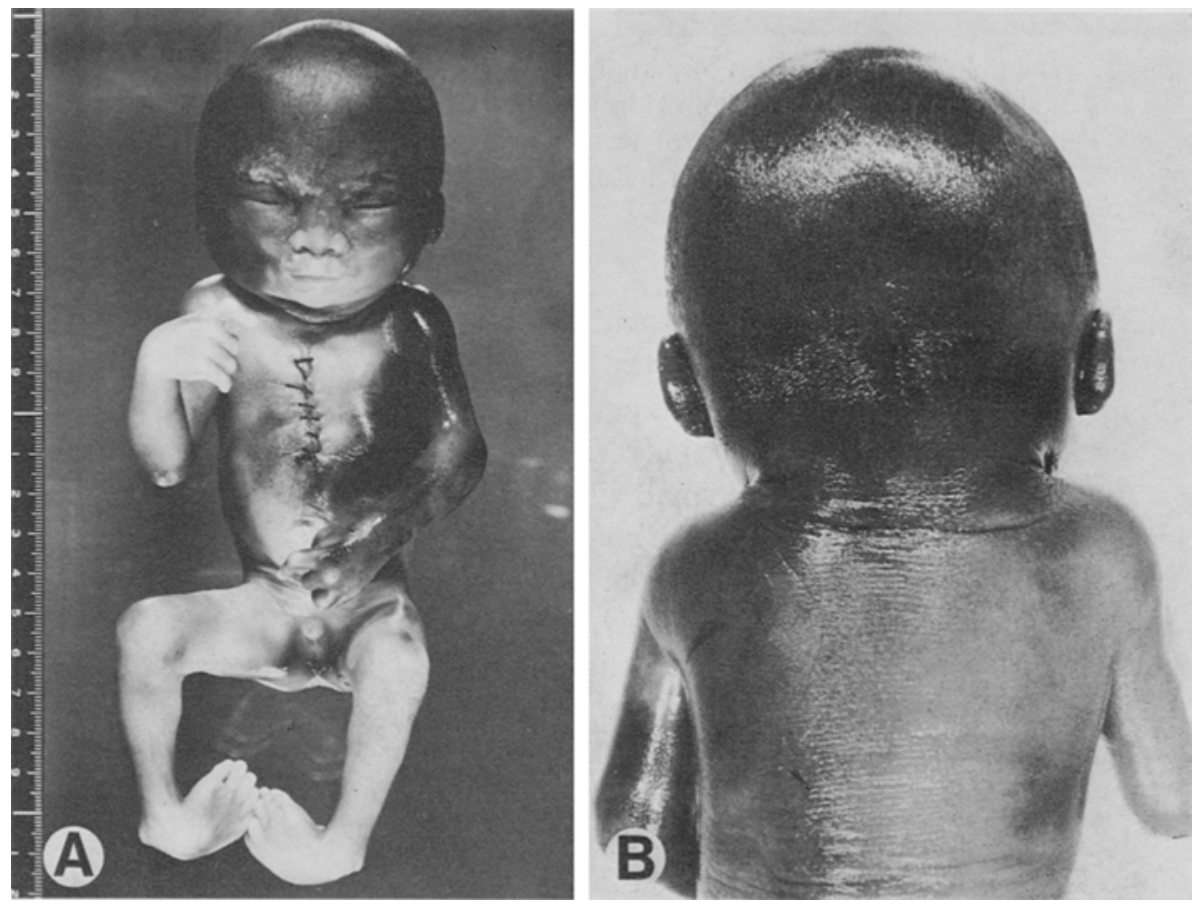

Fig. 2. The fetus of partial trisomy 6q. A. Anterior view showing the characteristic face, fingers and feet. B. Posterior view showing the short and webbed neck. 

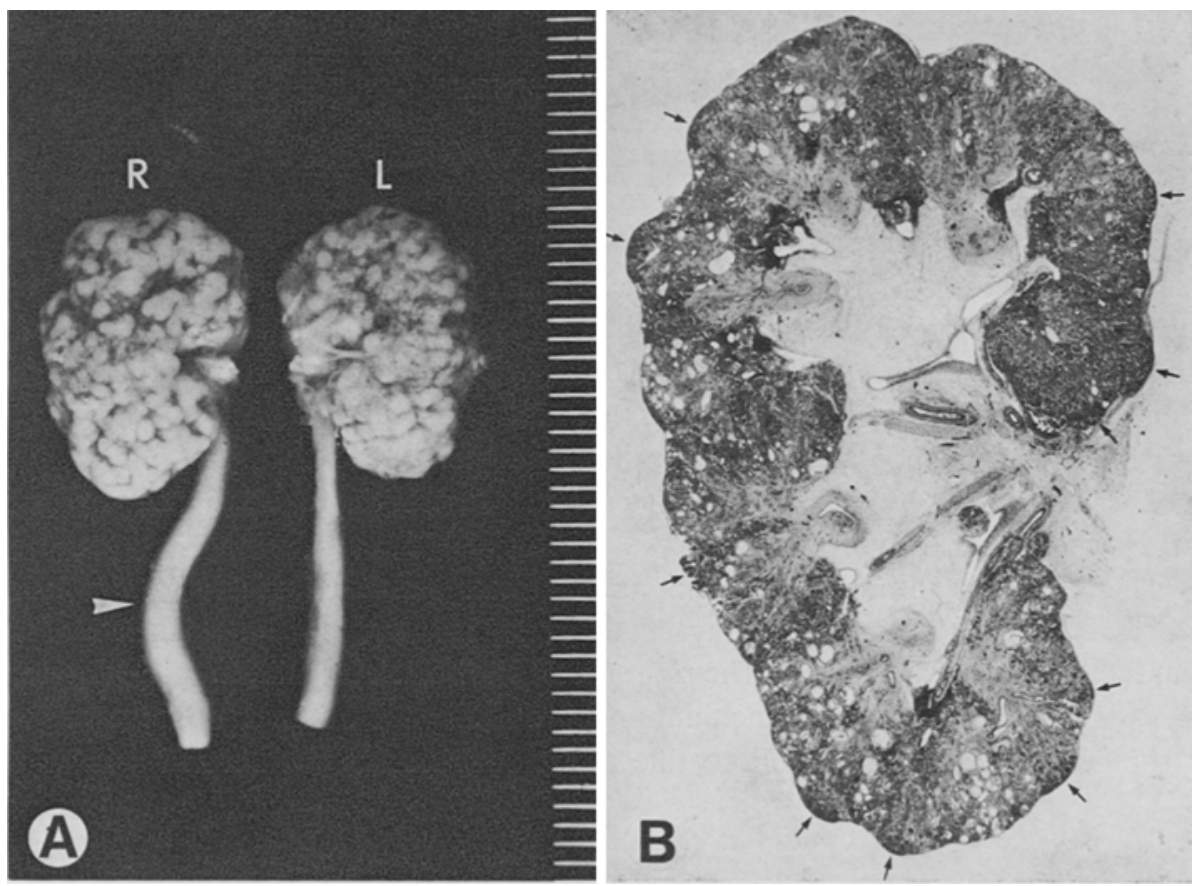

Fig. 3. The kidney from the fetus of partial trisomy 6q. A. Note the irregular-shaped nodules on the surface of both kidneys. The right ureter dilated slightly (arrowhead). B. Photomicrograph of the left kidney in Fig. 3A. The nephrogenic tissues (arrows) are present in localized area corresponding to the nodules of the surface.

nodules on the surface (Figs. 3A, 3B and 4A). Some islands of the nephrogenic tissues were also seen in the deeper cortex.

Another characteristics feature was cystic dilatation of the tubules. These small cysts were present in just those portions where the nephrogenic islands were absent (Figs. 3B and 4B). Walls of the small cysts were lined with diverse types of epithelial cells. The lining of some consisted of polyhedral cells with brush border, which suggested the proximal segment of the nephron. These cells often showed hydropic degeneration. More commonly, however, the lining of small cysts was cuboidal or flattened, which made its assignment to a specific segment of nephron or collecting tubule equivocal. In yet another group of cysts, an abrupt transition of the lining was noted, that is, from swollen epithelium with brush border to flattened epithelium (Fig. 4B). The testes were present in the lower abdominal cavity. The left testis $(0.04 \mathrm{~g})$ was smaller than the right $(0.09 \mathrm{~g})$. No significant differences in histological nature were present between them. 

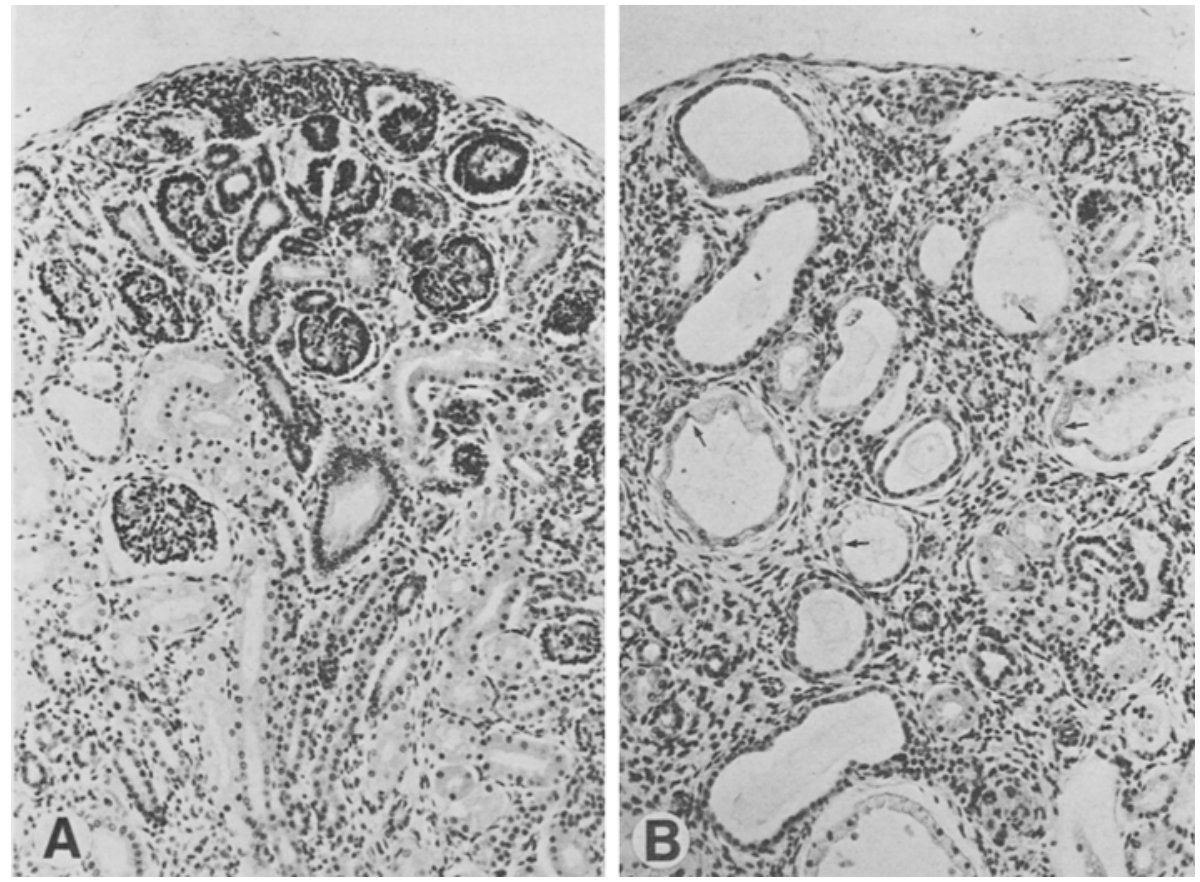

Fig. 4. Photomicrographs of the kidney from the fetus of partial trisomy 6q. A. Nephrogenic tissues in the nodular area of the surface. B. Small cysts in the cortex with the different kinds of lining epithelium. Arrows indicate abrupt transition of the epithelium.

\section{DISCUSSION}

Eight cases of partial trisomy $6 \mathrm{q}$ have thus far been described in children and adolescents (Robertson et al., 1975; Chen et al., 1976; Clark, 1977; Schmid et al., 1979; Tipton et al., 1979; Fujita, 1981). To the best knowledge of the authors, the present case is the first autopsy report on a fetus with partial trisomy $6 \mathrm{q}$. There were one mother who had two cases of partial trisomy $6 \mathrm{q}$. Duplication of $6 \mathrm{q}$ originated from balanced translocation of mother in seven cases, from that of father in one case, and resulted de novo in one case.

Morphological abnormalities in cases of partial trisomy $6 \mathrm{q}$ are listed in Table 1. Chief abnormal features are similar among them, although some minor variances are recognized. It is remarkable that such a young fetus as the present case, 5 months into pregnancy, exhibited the typical phenotype of partial trisomy 6q. Morphological divergence in each case may be accounted for by varying lengths of the duplicated segment of $6 \mathrm{q}$ and/or monosomy for a small segment lost from the recipient chromosome in the case of reciprocal translocation (Tipton et al., 1979). 
Table 1. Comparison of the present and previously reported cases of partial trisomy 6q.

\begin{tabular}{|c|c|c|c|c|c|c|}
\hline & $\begin{array}{l}\text { Present } \\
\text { case }\end{array}$ & $\begin{array}{l}\text { Robertson } \\
\quad \text { et al. }\end{array}$ & $\begin{array}{l}\text { Chen } \\
\text { et al. }\end{array}$ & $\begin{array}{l}\text { Chen } \\
\text { et al. }\end{array}$ & $\begin{array}{l}\text { Schmid } \\
\text { et al. }\end{array}$ & $\begin{array}{l}\text { Tipton } \\
\text { et al. }\end{array}$ \\
\hline Duplicated segment & $6 \mathrm{p} 21-\operatorname{ter}$ & $6 \mathrm{q} 21$-ter & $6 q 15-q 27$ & $6 q 15-q 27$ & 6q25-ter & 6q21-ter \\
\hline Age & $\begin{array}{l}19 \text { weeks } \\
\text { of preg. }\end{array}$ & 8 mos. & 20 mos. & 19 yrs. & 7 yrs. & 14 yrs. \\
\hline Sex & M & $\mathrm{F}$ & $M$ & M & $\mathbf{M}$ & $\mathrm{F}$ \\
\hline Low birth weight & & + & - & + & + & + \\
\hline Mental retardation & & $?$ & + & + & + & + \\
\hline Microcephaly & - & + & + & + & + & + \\
\hline $\begin{array}{l}\text { Downward slanting } \\
\text { palpebral fissures }\end{array}$ & - & $\ldots$ & + & + & - & + \\
\hline Hypertelorism & + & + & + & + & - & - \\
\hline Flat nasal bridge & + & - & + & + & $\ldots$ & + \\
\hline Long philtum & + & - & + & + & - & - \\
\hline Fish mouth & + & + & + & + & + & + \\
\hline Micrognathia & - & + & - & - & + & + \\
\hline Receding chin & + & - & + & + & + & - \\
\hline Short webbed neck & + & - & - & - & + & + \\
\hline Club foot & + & + & - & - & + & + \\
\hline Cardiovascular anomaly & + & - & - & - & - & - \\
\hline Renal anomaly & + & - & - & - & - & - \\
\hline
\end{tabular}

Total 3 cases of Clark, 1977 and Fujita, 1981 were excluded, because of incomplete description.

It is interesting to note that many spontaneous abortions, 12 in total, were recorded in four of eight mothers with partial trisomy $6 \mathrm{q}$ progeny. One such abortus, the fourth product of the present parents, was cytogenetically proved to be partial trisomy $6 \mathrm{q}$, although its morphological features were not recorded.

The present case is the first in whom renal abnormality is associated with partial trisomy 6q. Multiple cysts of the kidney have been mentioned in trisomies 13 and 18 (Egli and Stalder, 1973), but those with localized nephrogenic tissues have never been recorded in such a young fetus with chromosomal abnormality as ours. Due to a lack of sufficient nephrogenic zones, the kidneys of the present fetus could not have developed gradually toward term. The nodular surface with localized nephrogenic tissues might give an impression that it is what Bove and McAdams (1976) refered to as nephroblastomatosis, which they proposed, together with nodular renal blastema, as precursors to Wilms' tumor in children. The lesion of the present fetus, however, lacks the kind of definite proliferative nature that a precursor of Wilms' tumor exhibits. The lesion is rather interpreted as renal dysplasia with multiple cysts which might be associated with chromosomal abnormality. It may be taken as constituting the malformation-dysplasia syndrome (Herrmann et al., 1977). 
Coarctation of the aorta with persistent superior vena cava as well as cystic hygroma were often encountered in spontaneously aborted 45, X fetuses (Byrne et al., 1984). Besides these abnormalities, $45, \mathrm{X}$ fetuses are sometimes associated with renal anomalies, especially horse-shoe kidney (Singh and Carr, 1966; Byrne et al., 1984). The present fetus is somewhat similar to $45, \mathrm{X}$ fetuses in its phenotypic expression in that it has coarctation of the aorta with persistent superior vena cava, webbed neck and dysplastic kidneys. Despite their partial phenotypic coincidence, the two aneuploid conditions are easily distinguished with the aid of other morphological features.

Acknowledgment The authors thank Prof. K. Misugi, Department of Pathology, Yokohama City University School of Medicine, for his valuable advice.

\section{REFERENCES}

Bove, K.E. and McAdams, A.J. 1976. The nephroblastomatosis complex and its relationship to Wilms' tumor: A clinicopathologic treaties. In Perspectives in Pediatric Pathology, Rosenberg, H.S. and Bolande, R.P., eds., Vol. 3, Year Book Med., Chicago, pp. 185-223.

Byrne, J., Blanc, W.A., Warburton, D., and Wigger, J. 1984. The significance of cystic hygroma in fetuses. Hum. Pathol. 15: 61-67.

Chen, H., Tyrkus, M., Cohen, F., Woolley, P.V., Jr., Mayeda, K., Bhogaonker, A., Espiritu, C.E., and Simpson, W. 1976. Familial partial trisomy $6 \mathrm{q}$ syndromes resulting from inherited ins $(5 ; 6)$ (q33;q15;q27). Clin. Genet. 9: 631-637.

Clark, C. 1977. Partial trisomy of $6 \mathrm{q}$ in two siblings with multiple defects. Excerpta Medica, International Congress Series, 426: 40 (Abstract).

Egli, F. and Stalder, G. 1973. Malformations of kidney and urinary tract in common chromosomal aberrations. I. Clinical studies. Humangenetik 18: 1-15.

Fujita, H. 1981. Trisomy 6q. In Atlas of Chromosomal Syndromes, Abe, T. and Fujita, H., eds., Nankodo, Tokyo, pp. 147-149.

Herrmann, J., Gilbert, E.F., and Opitz, J.M. 1977. Dysplasia, malformations and cancer, especially with respect to Wiedemann-Beckwith syndrome. In Regulation of Cell Proliferation and Differentiation, Nichols, W.W. and Murphy, D.G., eds., Plenum Press, New York, pp. 1-64.

Miyabara, S., Suzumori, K., Saito, N., Matsumoto, M., Ikenoue, T., and Shiota, K. 1985. A fetopathological study of prenatally diagnosed fetuses. 1. A preliminary report. Teratology 32 (Abstract): 25B.

Robertson, K.P., Thurmon, T.F., and Tracy, M.C. 1975. Acrocephalosyndactyly and partial trisomy 6. Birth Defects, Original Article Series XI, No. 5, pp. 267-271.

Schmid, W., D'Apuzzo, V., and Rossi, E. 1979. Trisomy 6q25-6qter in a severely retarded 7-yearold boy with turricephaly, bow-shaped mouth, hypogenitalism and club feet. Hum. Genet. 46: 279-284.

Singh, R.P. and Carr, D.H. 1966. The anatomy and histology of XO human embryos and fetuses. Anat. Rec. 155: 369-384.

Tipton, R.E., Berns, J.S., Johnson, W.E., Wilroy, R.S., and Summitt, R.L. 1979. Duplication 6q syndrome. Am. J. Med. Genet. 3: 325-330. 